\title{
Terrestrial denitrification: challenges and opportunities
}

\author{
Peter M Groffman
}

\begin{abstract}
Denitrification is a process of great environmental importance but is difficult to study in terrestrial ecosystems. Methods for quantifying the process are problematic, variability in activity is high, and temporal and spatial scaling challenges are extreme. Available methods are problematic for a variety of reasons; they change substrate concentrations, disturb the physical setting of the process, lack sensitivity or are prohibitively costly in time and expense. Most fundamentally, it is very difficult to quantify the dominant end-product $\left(\mathrm{N}_{2}\right)$ of denitrification given its high background concentration in the atmosphere. Spatial and temporal variation in denitrification is high due to control of the process by multiple factors (oxygen, nitrate, carbon, pH, salinity, temperature etc.) that each vary in time and space. A particular challenge is that small areas (hotspots) and brief periods (hot moments) frequently account for a high percentage of $\mathrm{N}$ gas flux activity. These phenomena are challenging to account for in measurement, modeling and scaling efforts. The need for scaling is driven by the fact that there is a need for information on this microscale process at the ecosystem, landscape and regional scales where there are concerns about nitrogen effects on soil fertility, water quality and air quality. In this review, I outline the key challenges involved with denitrification and then describe specific opportunities for making progress on these challenges including advances in measurement methods, new conceptual approaches for addressing hotspot and hot moment dynamics, and new remote sensing and geographic information system-based scaling methods. Analysis of these opportunities suggests that we are poised to make great improvements in our understanding of terrestrial denitrification. These improvements will increase our basic science understanding of a complex biogeochemical process and our ability to manage widespread nitrogen pollution problems.
\end{abstract}

\section{Introduction}

Denitrification refers to the reduction of the nitrogen (N) oxides nitrate $\left(\mathrm{NO}_{3}^{-}\right)$and nitrite $\left(\mathrm{NO}_{2}^{-}\right)$to the $\mathrm{N}$ gases nitric oxide $(\mathrm{NO})$, nitrous oxide $\left(\mathrm{N}_{2} \mathrm{O}\right)$ and dinitrogen $\left(\mathrm{N}_{2}\right)$. The process is carried out primarily (but not exclusively) by facultatively anaerobic bacteria that normally respire oxygen $\left(\mathrm{O}_{2}\right)$ but in its absence respire the $\mathrm{N}$ oxides. Most denitrifying bacteria are heterotrophs, requiring organic compounds as an energy source. More than 60 genera of denitrifying microorganisms have been identified and denitrifiers represent up to $5 \%$ of the total soil microbial community (Philippot et al. 2007; Wallenstein et al. 2006).

At the organismal scale, denitrification is regulated by $\mathrm{O}_{2}$ and levels of available inorganic $\mathrm{N}$ and respirable

Correspondence: groffmanp@caryinstitute.org

Cary Institute of Ecosystem Studies, 2801 Sharon Turnpike, Millbrook, NY 12545, USA carbon (C) (Table 1). Regulation becomes more complex with increasing scale and requires analysis of relationships between the proximal, process-level factors that control flux (inorganic $\mathrm{N}$ levels, $\mathrm{O}_{2}$, available $\mathrm{C}$ ) and distal factors that control them at the scale of interest (Table 1) (Groffman 1991). For example, if we are studying $\mathrm{N}$ gas fluxes at the scale of field plots, we focus on soil moisture as a field-scale controller of the flow of $\mathrm{O}_{2}$ to the organisms that produce $\mathrm{N}$ gases. At the landscape scale, we measure soil texture and topography as landscape-scale controllers of soil moisture, landscape water fluxes and groundwater table distance. And at the regional scale, we focus on geology (surface and groundwater), geomorphic features (e.g., glacial till versus outwash) and land use as regional-scale controllers of soil texture and topography. Temporal regulation also varies with scale. While the presence of $\mathrm{O}_{2}, \mathrm{NO}_{3}^{-}$and $\mathrm{C}$ regulates denitrification activity at the scale of minutes and hours, we need to focus on rainfall events, seasonal

\section{并 Springer}




\begin{tabular}{|c|c|}
\hline Scale of investigation & Controlling factors \\
\hline Organism. . & Oxygen, inorganic $\mathrm{N}$, available $\mathrm{C}$ \\
\hline Field. .................... & $\begin{array}{l}\text { Soil water, inorganic } \mathrm{N} \text { supply, } \\
\text { available } \mathrm{C} \text { supply, } \mathrm{pH} \text {, } \\
\text { temperature, salinity, etc. }\end{array}$ \\
\hline Landscape. ........................ & $\begin{array}{l}\text { Soil type, plant community type, } \\
\text { canopy nutrients, season }\end{array}$ \\
\hline Global. . & Biome type, climate \\
\hline
\end{tabular}

weather patterns, management activities, and annual and decadal climate variation as regulators at daily, seasonal, annual and longer time scales.

The need for information on denitrification at ecosystem $(10 \mathrm{~m})$, landscape $(1,000 \mathrm{~m})$, regional $(>100 \mathrm{~km})$ and global scales is pressing. At the ecosystem scale, $\mathrm{N}$ gas fluxes can deplete soil stocks of inorganic $\mathrm{N}$, an essential and frequently limiting nutrient (Vitousek \& Howarth 1991). At the landscape scale, denitrification can prevent the movement of excess inorganic $\mathrm{N}$ from terrestrial environments into water bodies where it can cause overgrowth of aquatic plants and eutrophication (Seitzinger et al. 2006). There is a great need for information on the yield of $\mathrm{N}_{2} \mathrm{O}$ during denitrification as it is a "greenhouse" gas that can influence the earth's radiative budget and plays a role in stratospheric ozone destruction (Prather et al. 1995). Nitric oxide is a highly reactive gas that is a precursor to tropospheric ozone formation and is readily converted to $\mathrm{NO}_{2}$ and deposited back to the earth's surface in acid precipitation (NRC 1992). Interest in denitrification is particularly high in areas where $\mathrm{N}$ use is high, such as North America, Europe and Asia where there is great uncertainty over the fate of anthropogenic $\mathrm{N}$ inputs and concern about environmental effects (Davidson et al. 2012; Erisman et al. 2011).

Because the factors that influence $\mathrm{N}$ gas production all have complex underlying drivers of their own, $\mathrm{N}$ gas fluxes often exhibit extreme variation in time and space (Folorunso \& Rolston 1984; Parkin et al. 1987; Robertson et al. 1988). At certain times and places, these factors converge to create high rates of activity resulting in small areas (hotspots) and brief periods (hot moments) that frequently account for a high percentage of $\mathrm{N}$ gas flux activity. Moreover, it is difficult to measure fluxes without disturbing the physical soil environment and/or the biological processes that produce the fluxes, leading to frequent concerns that observed results are artifacts of a particular method (Groffman et al. 2006). Methodological problems and high variability are especially a concern when extrapolating point measurements to larger areas and longer time periods. Extrapolating highly variable estimates produced using problematic methods in time and space creates extreme uncertainty and low confidence in these scaled estimates.

In this review, I make the case that several recent developments suggest that our understanding of denitrification is about to markedly improve. At the organismal scale, new molecular methods are transforming our understanding of the organisms and communities that carry out denitrification (note that these methods are not the subject of this review, which focuses on the ecosystem scale and above). Methodological advances have led to improved quantification of the fluxes of all three gaseous products of denitrification. There have also been recent improvements in the development of remote sensing, geographic information system and simulation modeling tools for scaling gas flux measurements to larger areas. Stable isotope mass balance modeling and measurement techniques provide new approaches to constraining estimates of denitrification integrated over several temporal and spatial scales. Most fundamentally, there are new ideas and measurement approaches that can encompass the hotspot and hot moment phenomena that are so important for denitrification. Improved methods, applied in novel experimental designs that incorporate hotspot and hot moment phenomena and coupled with powerful scaling tools, have the potential to reduce the uncertainty in estimates of denitrification. These advances (reviewed below) suggest that we may soon have more definitive assessments of denitrification rates and of the importance of this process in ecosystem, landscape, regional and global $\mathrm{N}$ cycles.

\section{The challenge of denitrification-where does all the $\mathbf{N}$ go?}

Researchers and managers have struggled with "the enigma of missing N" for over four decades (Allison 1955; Van Breemen et al. 2002). This enigma arises from the computation of mass balances at multiple scales showing that inputs of $\mathrm{N}$ to watersheds from fertilizer, atmospheric deposition and human food/sewage are always much greater than outputs of $\mathrm{N}$ in stream flow and/or groundwater (Boyer et al. 2002; Howarth et al. 1996; Söderlund \& Svensson 1977). Indeed, global mass balance analyses (Seitzinger et al. 2006) suggest that the biggest global sink for anthropogenic $\mathrm{N}$ must be terrestrial denitrification (Figures 1 and 2), or perhaps $\mathrm{N}_{2}$ flux associated with anaerobic oxidation of ammonia (ANAMMOX) (Yang et al. 2012), yet there are few direct measurements to support these results.

At very large (regional and global) scales, $\mathrm{N}$ imbalances are "explained away" by a mixture of storage in soils and vegetation and/or high rates of denitrification in soils and sediments somewhere within the watershed (David \& Gentry 2000; Goodale et al. 2002; Howarth et al. 1996; Van Breemen et al. 2002). But the imbalances 


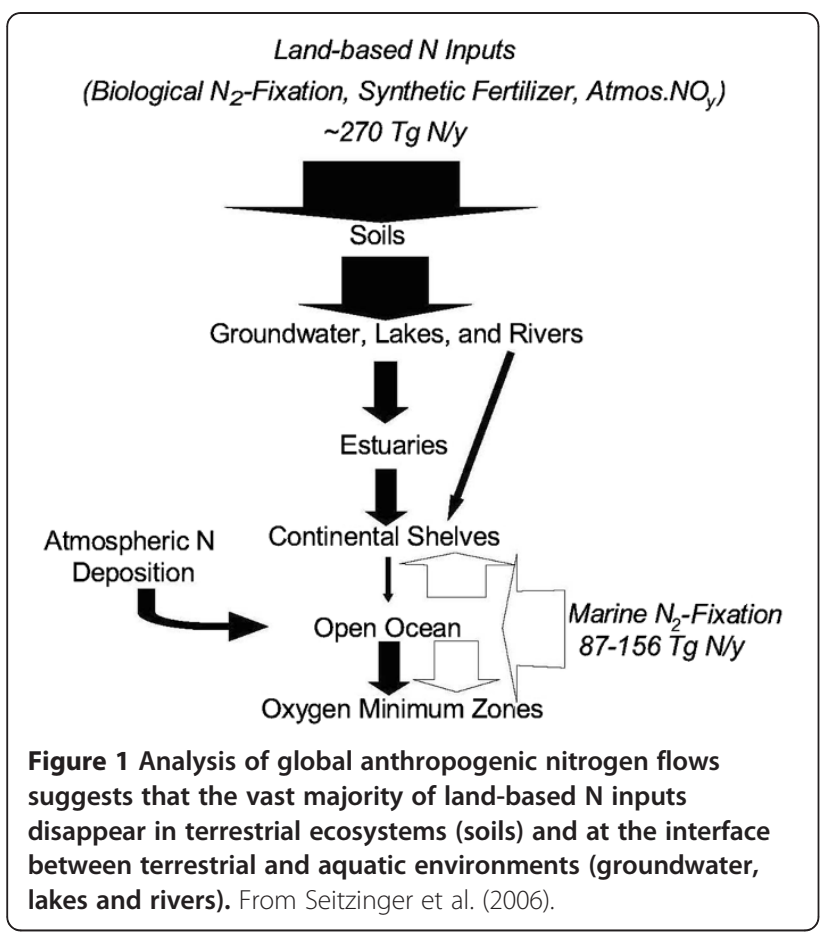

are harder to explain in more highly resolved analyses. For example, van Breemen et al. (2002) compiled detailed mass balances for 16 catchments $(\sim 500$ to $70,000 \mathrm{~km}^{2}$ ) along a latitudinal profile from Maine to Virginia, USA and made a "best guess" that terrestrial denitrification accounted for $37 \%$ of anthropogenic inputs in these watersheds (Figure 3). Yet measured denitrification rates in this region have never been high enough to be consistent with this estimate.

Imbalances in detailed studies at smaller scales, where plant and soil processes are carefully accounted for, are more difficult to explain than in large scale balances (Addiscott 1995; Lowrance 1992; Steinheimer et al. 1998). For example, analysis of the fates of fertilizer $\mathrm{N}$ added over 22 years in an Iowa watershed with continuous corn show large amounts of "unaccounted for (lost or stored) N" (Figure 4). Given that these agricultural soils are likely not accumulating organic $\mathrm{N}$, the vast majority of the "lost or stored" $\mathrm{N}$ was likely denitrified. Yet, measurements suggest that these well drained agricultural soils are not likely to be denitrifying at a high rate (Hofstra \& Bouwman 2005). These inconsistencies challenge our fundamental understanding of the $\mathrm{N}$ cycle.

Addressing the challenge of denitrification requires advances in three main areas: (1) improved methods for quantifying $\mathrm{N}$ gas fluxes, (2) experimental designs that incorporate hotspot and hot moment phenomena and (3) approaches for temporal and spatial scaling that account for hotspot and hot moment phenomena at multiple scales. Below, I review the challenges and opportunities in each of these three areas.

It is important to note that this review does not comprehensively address recent advances in molecular and microbial studies of denitrification or other dissimilatory fates of $\mathrm{N}$ such as dissimilatory $\mathrm{NO}_{3}^{-}$reduction to ammonia (DNRA) (Burgin \& Hamilton 2007) or $\mathrm{N}_{2}$ production associated with ANAMMOX (Yang et al. 2012). These topics, with some key references are mentioned

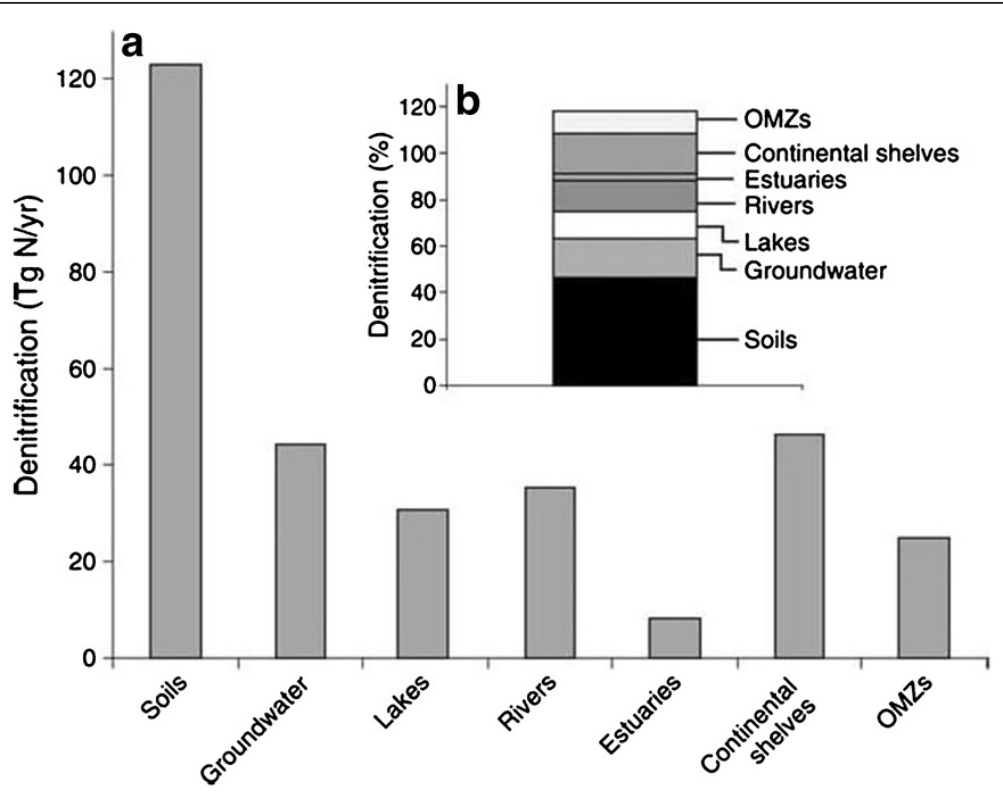

Figure 2 Denitrification of land-based N sources in terrestrial, freshwater, and marine ecosystems globally shows that terrestrial ecosystems (soils) and the interface between terrestrial and aquatic environments (groundwater, lakes and rivers) dominate global denitrification in terms of mass flux (a) and as a percentage of land-based $\mathbf{N}$ sources (b). From Seitzinger et al. (2006). 


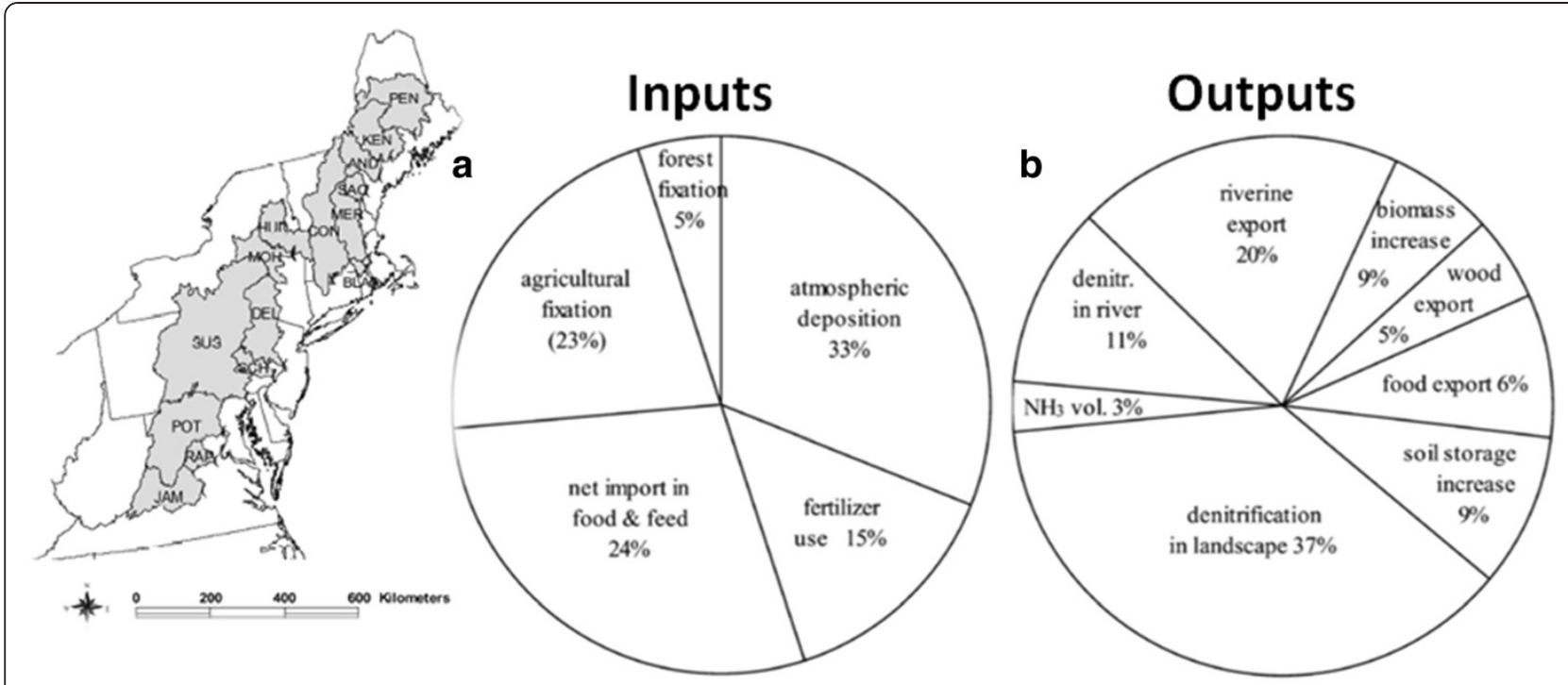

Figure 3 Nitrogen budgets describing "best guesses" of (a) nitrogen sources and (b) nitrogen storages and losses for 16 catchments along a latitudinal profile from Maine to Virginia, USA. Values are the weighted average for the 16 watersheds. From Van Breemen et al. (2002).

briefly, but the focus here is on the potential for improvements in estimates of terrestrial denitrification relevant to $\mathrm{N}$ pollution questions at ecosystem, landscape and regional scales.

\section{Challenges and opportunities in methods for quantifying $\mathbf{N}$ gas fluxes}

Denitrification has always been a challenging process to measure (Groffman et al. 2006), primarily due to the

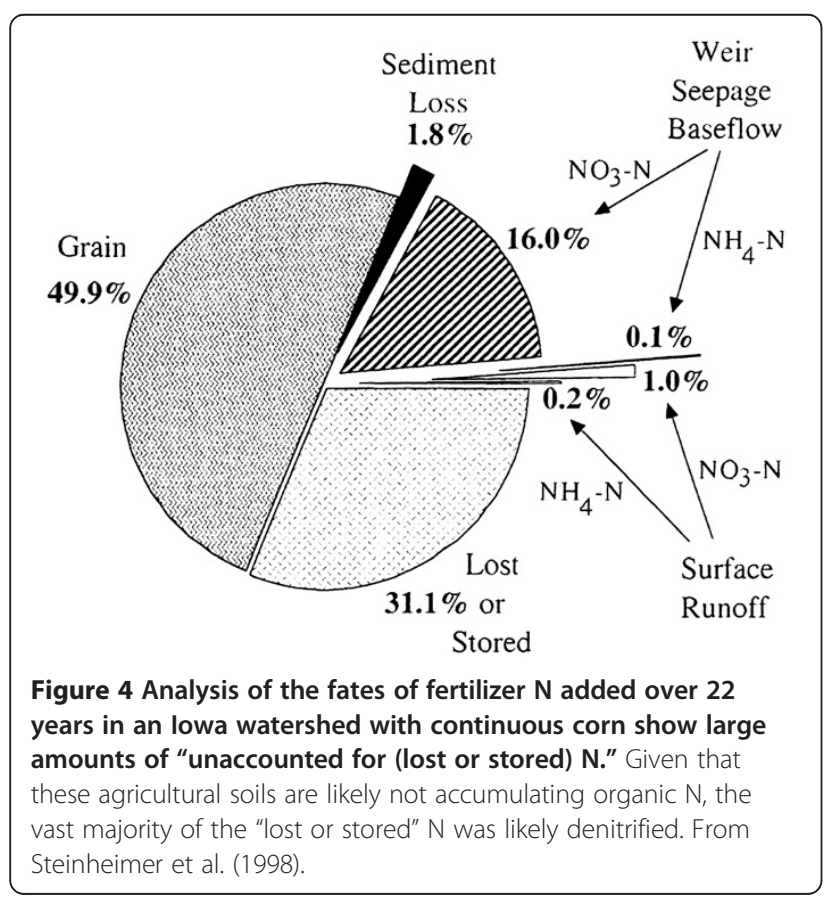

difficulty of quantifying the flux of $\mathrm{N}_{2}$ from soil against the high natural atmospheric background of this gas (Yang \& Silver 2012). Most denitrification methods therefore involve alteration of physical or chemical conditions through the use of inhibitors (e.g., acetylene) or amendments (e.g., $\left.{ }^{15} \mathrm{~N}\right)$ that produce inaccurate or unrealistic estimates of rates. Most methods also involve the use of relatively small samples (e.g., $5 \mathrm{~cm}$ diameter soil cores) that exacerbate problems with variability and hotspots. However, there have been recent advances in methods for quantifying $\mathrm{N}_{2}$ flux and in isotope-based methods that provide area and time-integrated estimates of denitrification that are more relevant to ecosystemscale questions.

Recent efforts to quantify $\mathrm{N}_{2}$ flux have centered on the use of soil core-based gas recirculation systems that allow for replacement of the natural $\mathrm{N}_{2} / \mathrm{O}_{2}$ atmosphere with a $\mathrm{He} / \mathrm{O}_{2}$ atmosphere, allowing for direct measurement of $\mathrm{N}_{2}$ and $\mathrm{N}_{2} \mathrm{O}$ production (Butterbach-Bahl et al. 2002; Swerts et al. 1995; Wang et al. 2011a). These systems allow for direct assessment of $\mathrm{N}_{2} \mathrm{O}$ fluxes and of $\mathrm{N}_{2} \mathrm{O}: \mathrm{N}_{2}$ yields (Burgin \& Groffman 2012) but still involve the use of extracted soil cores, over extended periods, which can create multiple effects on $\mathrm{N}$ cycle process rates (Frank \& Groffman 2009). The realism of flux estimates from cores can be checked at least partially by comparing estimates of $\mathrm{CO}_{2}$ and $\mathrm{N}_{2} \mathrm{O}$ fluxes from the cores with estimates from field chambers. Ultimately, it may be possible to directly measure $\mathrm{N}_{2}$ fluxes or $\mathrm{N}_{2}$ :Ar ratios from field chambers (Yang \& Silver 2012) or to measure fluxes of ${ }^{15} \mathrm{~N}_{2}$ following tracer level additions of ${ }^{15} \mathrm{NO}_{3}^{-}$to field chambers (Stange et al. 
2009). Development of these methods will require improvements in the sensitivity of membrane inlet and/ or isotope ratio mass spectrometry. Isotope addition approaches are also essential for separating different dissimilatory fates of inorganic $\mathrm{N}$, i.e., denitrification versus ANAMMOX (Yang et al. 2012) and DNRA (Nicholls \& Trimmer 2009).

The ability to vary the $\mathrm{O}_{2}$ concentration of the recirculation stream in the new soil core methods provides a basis for temporal extrapolation and for including hot moments of flux driven by decreases in $\mathrm{O}_{2}$ caused by rainfall events. If continuous estimates of soil $\mathrm{O}_{2}$ can be produced either from sensors or from models, denitrification versus $\mathrm{O}_{2}$ relationships established with the recirculation system can be used to produce continuous estimates of flux (Burgin \& Groffman 2012; Burgin et al. 2010). These sensors provide a new opportunity to quantify the dominant proximal controller of denitrification at high temporal resolution and can reveal surprising insights on this controller. In a forested riparian zone in New York, USA, we observed marked differences in soil $\mathrm{O}_{2}$ over very short distances and time periods (Figure 5), greatly improving depiction of just where and when denitrification was likely to be occurring at this site.

While it has long been known that the lighter isotope of $\mathrm{N}\left({ }^{14} \mathrm{~N}\right)$ is preferentially consumed during denitrification, resulting in enrichment of soils in ${ }^{15} \mathrm{~N}$, recent efforts to constrain biogeochemical models with isotope data have produced improved assessments of denitrification at ecosystem (Amundson et al. 2003; Bai \& Houlton 2009; Houlton et al. 2006) and regional/global (Houlton \& Bai 2009) scales. These methods need to account for situations (e.g., very wet soils) where denitrification completely consumes $\mathrm{NO}_{3}^{-}$, eliminating any isotopic discrimination. $\mathrm{N}$ isotope budgets that account for such local effects can be used to produce independent estimates of denitrification that can be compared with direct measurements and simulation model outputs.

Stable isotopes can provide further information on the role of denitrification through measurements of both $\delta$ ${ }^{15} \mathrm{~N}$ - and $\delta{ }^{18} \mathrm{O}$ - values of residual $\mathrm{NO}_{3}^{-}$in soil (Casciotti et al. 2002; Huygens et al. 2005; Sigman et al. 2001). Denitrification enriches ${ }^{18} \mathrm{O}$ as well as ${ }^{15} \mathrm{~N}$ in the residual $\mathrm{NO}_{3}^{-}$, typically in a 1:2 ratio, providing an isotopic signature of $\mathrm{NO}_{3}^{-}$from denitrification different from that in atmospheric deposition or soil nitrification (Kendall 1998; Kendall et al. 2007), although there is recent concern that exchange of $\mathrm{O}_{2}$ between water and $\mathrm{NO}_{3}^{-}$can alter these patterns (Kool et al. 2011; Well \& Flessa 2009). This approach does not produce quantitative estimates of denitrification. However it can provide useful confirmation of estimates and patterns produced by other approaches.

\section{Challenges and opportunities in experimental designs that include hotspots and hot moment phenomena}

Much of the uncertainty about denitrification arises from the fact that small areas (hotspots) and brief periods (hot moments) frequently account for a high percentage of $\mathrm{N}$ gas flux activity. These phenomena are challenging to account for in measurement, modeling and scaling efforts (Groffman et al. 2009). The importance of hotspots and hot moments to denitrification activity became obvious in the 1970 s as techniques that allowed for measurement of denitrification in situ, especially in soils, produced observations of extremely high spatial and temporal variability in measured rates (Folorunso \& Rolston 1984; Rolston et al. 1979). Early efforts focused on hotspots in the anaerobic centers of soil aggregates (Sexstone et al. 1985; Smith 1980), along growing roots (Haider et al. 1987; Woldendorp 1962), at the aerobic/anaerobic interface of sediments (Reddy \& Patrick 1984) and in patches of labile organic matter (Christensen et al. 1990; Parkin 1987). Parkin (1987) dissected an intact soil core and determined that a very high percentage (more than $80 \%$ ) of the denitrification activity was taking place in and around a decomposing leaf that represented less than $1 \%$ of the core volume (Figure 6).

The hotspot concept is also useful at larger scales. For example, particular components of landscapes, e.g., riparian zones or areas of intensive agricultural activity within regions, are potential hotspots of denitrification (Butterbach-Bahl \& Dannenmann 2011; Harms \& Grimm 2008; McClain et al. 2003; Vidon et al. 2010). Expansion of the hotspot concept to landscape and regional scales was particularly important for producing estimates of denitrification relevant to $\mathrm{N}$-induced water and air quality problems.

The hot moment concept is rooted in the well established idea that bursts of activity following dryingrewetting and freezing-thawing events are important to $\mathrm{C}$ and $\mathrm{N}$ dynamics in soils (Birch 1958; Edwards \& Cresser 1992). Denitrification can be important during these events as the addition of water from rewetting or thawing can restrict $\mathrm{O}_{2}$ diffusion into soil, and bursts of respiration can consume significant amounts of $\mathrm{O}_{2}$ (Goodroad \& Keeney 1984; Groffman \& Tiedje 1988). Similar to hotspots, hot moments are also useful at larger scales. Particular seasons or seasonal transitions (e.g., snowmelt, early spring) or events (e.g., litterfall, floods) can account for a very high percentage of annual or decadal denitrification activity (McClain et al. 2003).

Recognition of the importance of hotspots and hot moments is a great aid to experimental design for denitrification studies. In any study, at any scale, investigators should design their study to encompass the small 


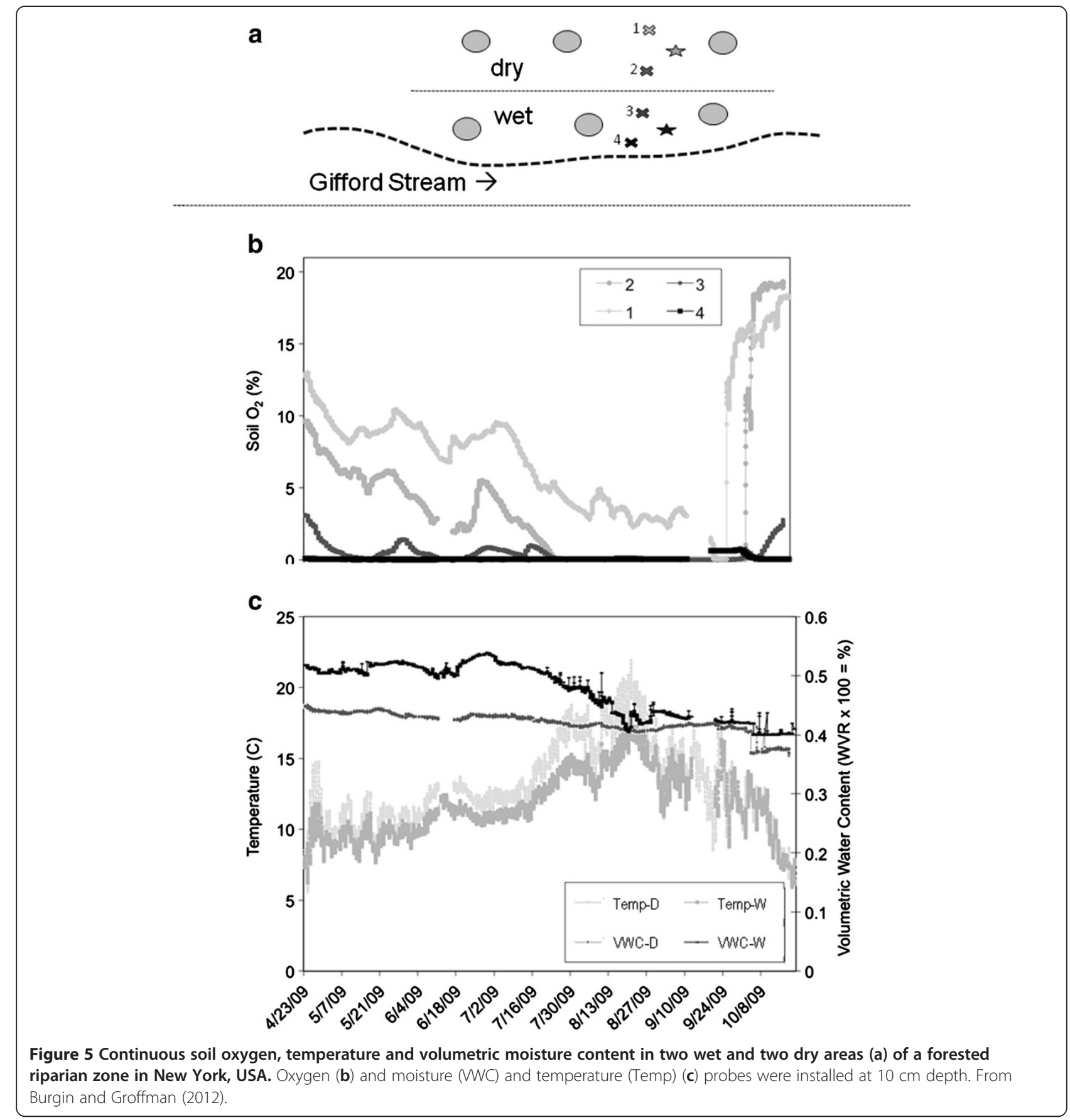

areas and brief periods that are likely to account for a significant amount of activity. For example in studies in crop fields, sampling campaigns need to account for low areas in the field that flood for brief periods (Gentry et al. 1998) and for seasonal transitions, e.g., snowmelt or harvest that could create suitable conditions for high rates of denitrification. Landscape-scale studies need to focus on riparian zones and other areas of "hydrologic convergence" that create optimal conditions for denitrification (Harms \& Grimm 2008; Tague et al. 2010; Vidon et al. 2010; Walter et al. 2000). In regional-scale studies, we need to focus on areas with high $\mathrm{N}$ inputs and/or wet soils. As our ability to conceptualize and then quantitatively map (discussed below) hotspots and hot moments increases, our experimental designs (and results and understanding) are likely to improve.

Recent advances in molecular and microbial approaches are likely to be an important aid to understanding the dynamics of hotspots and hot moments. As our ability to understand the factors regulating denitrifying communities 


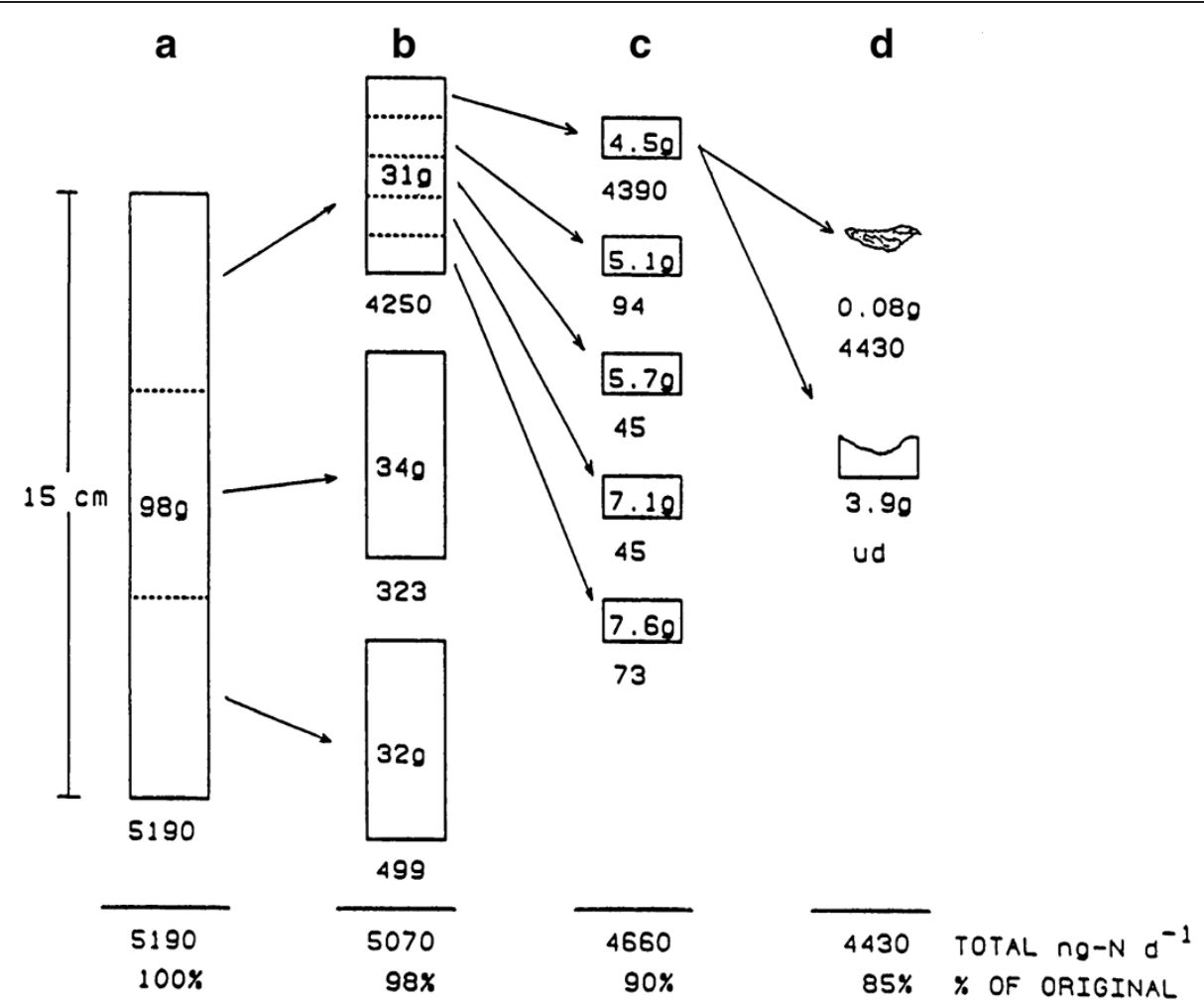

Figure 6 The importance of hotspots in a soil core. After measuring denitrification on the entire core (a), the core was split into three segments (b), which showed that most of the activity was occurring in the top segment. The top segment was then split into five sections (c), which showed that the majority of activity was occurring in the very top segment. This segment was dissected (d), which showed that $85 \%$ of the denitrification activity in the 5,190 g soil core was taking place in a $0.08 \mathrm{~g}$ piece of plant detritus. From Parkin (1987).

(Bergaust et al. 2011; Kandeler et al. 2006; Philippot et al. 2009; Wallenstein et al. 2006; Wang et al. 2011b) and microbial and molecular dynamics during episodes such as drying/rewetting events and other environmental changes (Attard et al. 2011; Enwall et al. 2010; Evans \& Wallenstein 2012) improves, it will become easier to incorporate these phenomena into experimental designs and sampling campaigns.

\section{Challenges and opportunities in temporal and spatial scaling}

Scaling information from small-scale point measurements to larger areas and time periods is a great challenge in many areas of environmental science but is especially challenging for denitrification due to inherently high variability at the microbial scale of the process. Yet there is a strong need for information on denitrification at relatively large spatial (meters to kilometers and larger) and temporal (years, decades) scales. Recent advances in scaling have come from improvements in the ability to identify and quantify the hotspots and hot moments that dominate denitrification fluxes and in simulation models that can be run over large areas and time periods.
Improvements in remote sensing and geographic information system technology have improved our ability to identify and quantify hotspots of denitrification at ecosystem, landscape and regional scales. For example, in forested ecosystems or landscapes, soil wetness and $\mathrm{N}$ availability are the dominant controllers of variation in denitrification (Groffman \& Tiedje 1989). New algorithms applied to high resolution digital elevation models can now depict the presence of wet areas in forested landscapes at high resolution (Beven 1997; Tague et al. 2010; Walter et al. 2000). At the same time, remote sensing estimates of foliar $\mathrm{N}$ or lignin: $\mathrm{N}$ provide a high resolution landscape- and regional-scale index of $\mathrm{N}$ cycle hotspots (Martin et al. 2008; Ollinger et al. 2008; Ollinger et al. 2002). Thus we now have landscape- and regionalscale tools capable of identifying and quantifying potential hotspots (Figure 7) of denitrification.

As described above, new soil $\mathrm{O}_{2}$ sensors or models can be used as temporal scaling tools if they can depict hot moments of activity driven by rainfall events or events such as snowmelt or litterfall. These dynamics are likely complex, however, as soil $\mathrm{O}_{2}$ is strongly affected by soil moisture, which inhibits diffusion of $\mathrm{O}_{2}$ into the soil, but also by soil respiration, which consumes $\mathrm{O}_{2}$ (Liptzin et al. 
2011; Silver et al. 1999). However, new ecohydrological models have the potential to model the presence of wet areas in the landscape as well as the biogeochemical processes that drive soil respiration (Butterbach-Bahl et al. 2004; Tague 2009).

Indeed there have been many advances in simulation models that facilitate scaling of denitrification estimates to large areas and long time periods. The DenitrificationDecomposition (or DNDC) model is a daily time-step model of $\mathrm{C}$ and $\mathrm{N}$ biogeochemistry that focuses on simulation of soil $\mathrm{O}_{2}$ levels and denitrification rates $(\mathrm{Li}$ et al. 2000). DNDC and other models can be linked to/driven by geographic information to produce landscape- and regional-scale estimates of denitrification (Butterbach-Bahl et al. 2001, 2004). Much of the motivation for model development has come from efforts to provide estimates of $\mathrm{N}_{2} \mathrm{O}$ flux at large scales for national- and regional-scale greenhouse gas inventories. It is easier to test the ability of a model to depict $\mathrm{N}_{2} \mathrm{O}$ fluxes, at least at the field chamber scale, than to test the ability of a model to depict total denitrification or $\mathrm{N}_{2}$ fluxes (David et al. 2009). There is a great need to evaluate the ability of these models to simulate $\mathrm{N}_{2}$ fluxes, either through model comparisons or by comparisons of measured fluxes and isotope measurements as discussed above.

The ecohydrological models that are based on spatially explicit depiction of the movement of water across the landscape (Beven \& Kirkby 1997) are perhaps the most promising modeling development to increase our ability to estimate denitrification at ecosystem, landscape and regional scales. These models process water and nutrients as they move though different landscape elements and therefore have the potential for depicting both hotspots and hot moments of denitrification activity if they operate at sufficiently high resolution (Band et al. 2001; Haas et al. 2012; Tague 2009; Tague \& Band 2004). Testing the denitrification algorithms in these models with field data and independent isotope approaches in
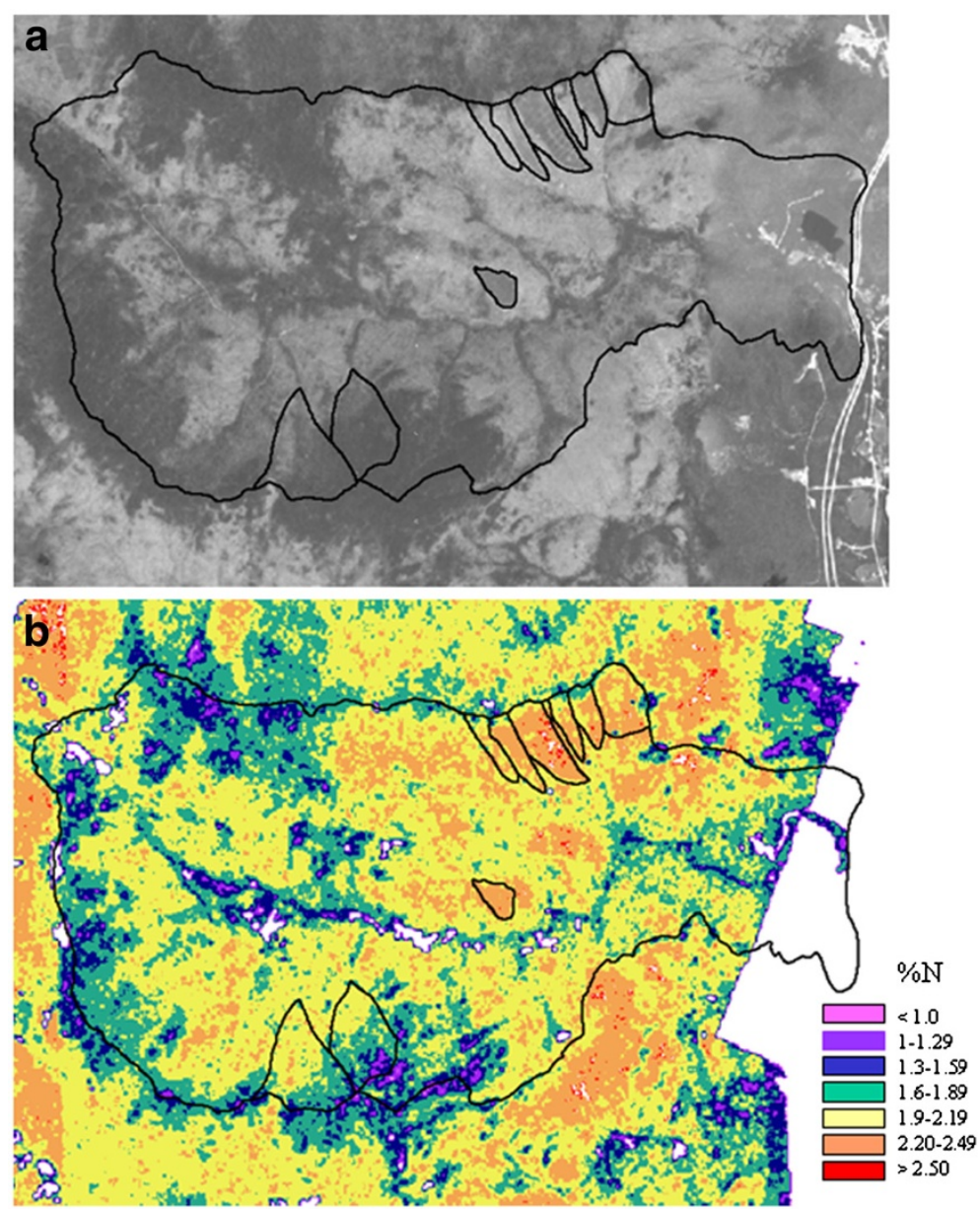

Figure 7 A topographic index of soil wetness (a) and AVIRIS-derived foliar N ( 17 m resolution) (b) and for the $\sim$ 3,000 ha Hubbard Brook Experimental Forest, NH, USA. Note "hotspots" of high foliar N (light colors) in the cutover watersheds in the top right corner of the image and dark areas of low foliar $\mathrm{N}$ in the conifer-dominated areas at the bottom/center and top left corners of the image. From Kulkarni et al. (2008). 
multiple sites could yield significant improvements in our understanding and estimates of denitrification at landscape and regional scales.

\section{Conclusions}

The need for information on terrestrial denitrification has never been greater. With keen societal interest in reactive $\mathrm{N}$ delivery to receiving waters and the atmosphere, there is a great need for information on denitrification rates and controlling factors. Lack of information on denitrification is a fundamental constraint on the ability of society to address $\mathrm{N}$ pollution problems in many areas (Davidson et al. 2012; Galloway et al. 2008).

However, new advances in methods, scaling and modeling make it quite likely that we will soon be able to meet societal needs for information on denitrification. Improved methods for measuring flux at the small scale can be combined with new approaches for scaling and/or modeling to produce estimates of denitrification that are increasingly relevant to questions about eutrophication of coastal water bodies and regional and global $\mathrm{N}_{2} \mathrm{O}$ budgets.

Efforts to improve estimates of terrestrial denitrification need to proceed in several areas. For methods, we need to move beyond extracted soil cores and push for improvements in mass spectrometry that will allow for direct quantification of $\mathrm{N}_{2}$ and/or tracer-level ${ }^{15} \mathrm{~N}_{2}$ in field plots. Ultimately, area-integrated (e.g., from eddy flux towers) measurements need to replace point (core) measurements. While this technology is developing nicely for $\mathrm{N}_{2} \mathrm{O}$, it remains very challenging to measure fluxes of $\mathrm{N}_{2}$ from the soil to the atmosphere. Isotope mass balance and modeling methods should continue to improve and should provide an important comparison/ validation of direct measurements.

At the same time, we need continued improvements in tools for detecting and quantifying the drivers of hotspot and hot moment phenomena at ecosystem, landscape and regional scales. Improvements in remote sensing of $\mathrm{N}$ richness and in geographic depiction of wet areas in the landscape are needed at high spatial and temporal resolution. Technology for continuous, often real-time, data on soil moisture, $\mathrm{O}_{2}$ and $\mathrm{NO}_{3}^{-}$is improving and should be a great aid to depicting hotspot and hot moment dynamics. Finally, there needs to be active interaction between measurement and modeling. Models must be used to evaluate the plausibility of scaled denitrification estimates, and point flux measurements must be used to validate model predictions.

Continued progress in denitrification research will be enhanced if multiple approaches are applied at wellstudied research sites (Davidson \& Seitzinger 2006). If new flux methods can be compared with stable isotope approaches and if multiple models can be applied at sites with well established mass balances, the chances that definitive estimates of denitrification will be produced are higher. Such a process will allow different methods and models to be compared with each other and against other, more easily quantified aspects of the $\mathrm{N}$ cycle. Denitrification will continue to be a challenging process to study for many decades to come. Progress is much more likely if research efforts are coordinated and cooperative.

\section{Competing interests}

The author declares that they have no competing interests.

\section{Acknowledgements}

This work was partially supported by U.S. National Science Foundation grant NSF DEB - 0919131. The manuscript was greatly improved by the comments of two anonymous reviewers.

Received: 21 August 2012 Accepted: 16 October 2012

Published: 8 November 2012

\section{References}

Addiscott TM (1995) Modelling the fate of crop nutrients in the environment: problems of scale and complexity. Eur J Agron 4:413-417

Allison FE (1955) The enigma of soil nitrogen balance sheets. Adv Agron 7:213-250

Amundson R, Austin AT, Schuur EAG, Yoo K, Matzek V, Kendall C, Uebersax A, Brenner D, Baisden WT (2003) Global patterns of the isotopic composition of soil and plant nitrogen. Global Biogeochem Cycles 17:GB001903

Attard E, Recous S, Chabbi A, De Berranger C, Guillaumaud N, Labreuche J, Philippot L, Schmid B, Le Roux X (2011) Soil environmental conditions rather than denitrifier abundance and diversity drive potential denitrification after changes in land uses. Glob Chang Biol 17:1975-1989

Bai E, Houlton BZ (2009) Coupled isotopic and process-based modeling of gaseous nitrogen losses from tropical rain forests. Global Biogeochem Cycles 23:GB003361

Band LE, Tague CL, Groffman P, Belt K (2001) Forest ecosystem processes at the watershed scale: hydrological and ecological controls of nitrogen export. Hydrol Processes 15:2013-2028

Bergaust L, Bakken LR, Frostegard A (2011) Denitrification regulatory phenotype, a new term for the characterization of denitrifying bacteria. Biochem Soc Trans 39:207-212

Beven KJ (ed) (1997) Distributed modelling in hydrology. Applications of TOPMODEL. Wiley, Chichester

Beven KJ, Kirkby MJ (1997) A physically-based variable contributing area model of basin hydrology. Hydrol Sci Bull 24:4369-4382

Birch $H$ (1958) The effect of soil drying on humus decomposition and nitrogen availability. Plant Soil 10:9-31

Boyer EW, Goodale CL, Jaworski NA, Howarth RW (2002) Anthropogenic nitrogen sources and relationships to riverine nitrogen export in the northeastern USA. Biogeochemistry 57:137-169

Burgin AJ, Groffman PM (2012) Soil $\mathrm{O}_{2}$ controls denitrification rates and $\mathrm{N}_{2} \mathrm{O}$ yield in a riparian wetland. J Geophys Res 117:G01010

Burgin AJ, Groffman PM, Lewis DN (2010) Factors regulating denitrification in a riparian wetland. Soil Sci Soc Am J 74:1826-1833

Burgin AJ, Hamilton SK (2007) Have we overemphasized the role of denitrification in aquatic ecosystems? A review of nitrate removal pathways. Front Ecol Environ 5:89-96

Butterbach-Bahl K, Dannenmann M (2011) Denitrification and associated soil $\mathrm{N}_{2} \mathrm{O}$ emissions due to agricultural activities in a changing climate. Curr Opin Environ Sustain 3:389-395

Butterbach-Bahl K, Stange F, Papen H, Li CS (2001) Regional inventory of nitric oxide and nitrous oxide emissions for forest soils of southeast Germany using the biogeochemical model PnET-N-DNDC. J Geophys Res Atmos 106:34155-34166

Butterbach-Bahl K, Willibald G, Papen H (2002) Soil core method for direct simultaneous determination of $\mathrm{N}-2$ and $\mathrm{N}_{2} \mathrm{O}$ emissions from forest soils. Plant Soil 240:105-116

Butterbach-Bahl K, Kesik M, Miehle P, Papen H, Li C (2004) Quantifying the regional source strength of $\mathrm{N}$-trace gases across agricultural and forest ecosystems with process based models. Plant Soil 260:311-329 
Casciotti KL, Sigman DM, Hastings MG, Bohlke JK, Hilkert A (2002) Measurement of the oxygen isotopic composition of nitrate in seawater and freshwater using the denitrifier method. Anal Chem 74:4905-4912

Christensen S, Simkins S, Tiedje JM (1990) Spatial variation in denitrification: dependency of activity centers on the soil environment. Soil Sci Soc Am J 54:1608-1613

David M, Del Grosso S, Hu X, Marshall E, Mclsaac G, Parton W, Tonitto C, Youssef M (2009) Modeling denitrification in a tile-drained, corn and soybean agroecosystem of Illinois, USA. Biogeochemistry 92:7-30

David MB, Gentry LE (2000) Anthropogenic inputs of nitrogen and phosphorus and riverine export for Illinois, USA. J Environ Qual 29:494-508

Davidson EA, Seitzinger S (2006) The enigma of progress in denitrification research. Ecol Appl 16:2057-2063

Davidson EA, David MB, Galloway JN, Goodale CL, Haeuber R, Harrison JA, Howarth RW, Jaynes DB, Lowrance RR, Nolan BT, Peel JL, Pinder RW, Porter E, Snyder CS, Townsend AR, Ward MH (2012) Excess nitrogen in the U.S. environment: trends, risks, and solutions. Issues Ecol 15:1-16

Edwards AC, Cresser MS (1992) Freezing and its effect on chemical and biological properties of soil. Adv Soil Sci 18:61-79

Enwall K, Throback IN, Stenberg M, Soderstrom M, Hallin S (2010) Soil resources influence spatial patterns of denitrifying communities at scales compatible with land management. Appl Environ Microbiol 76:2243-2250

Erisman JW, Galloway J, Seitzinger S, Bleeker A, Butterbach-Bahl K (2011) Reactive nitrogen in the environment and its effect on climate change. Curr Opin Environ Sustain 3:281-290

Evans S, Wallenstein M (2012) Soil microbial community response to drying and rewetting stress: does historical precipitation regime matter? Biogeochemistry 109:101-116

Folorunso OA, Rolston DE (1984) Spatial variability of field measured denitrification gas fluxes. Soil Sci Soc Am J 48:1214-1219

Frank DA, Groffman PM (2009) Plant rhizospheric N processes: what we don't know and why we should care. Ecology 90:1512-1519

Galloway JN, Townsend AR, Erisman JW, Bekunda M, Cai ZC, Freney JR, Martinell LA, Seitzinger SP, Sutton MA (2008) Transformation of the nitrogen cycle: recent trends, questions, and potential solutions. Science 320:889-892

Gentry LE, David MB, Smith KM, Kovacic DA (1998) Nitrogen cycling and tile drainage nitrate loss in a corn/soybean watershed. Agric Ecosyst Environ 68:85-97

Goodale CL, Lajtha K, Nadelhoffer KJ, Boyer EW, Jaworski NA (2002) Forest nitrogen sinks in large eastern US watersheds: estimates from forest inventory and an ecosystem model. Biogeochemistry 57:239-266

Goodroad LL, Keeney DR (1984) Nitrous oxide emissions from soils during thawing. Can J Soil Sci 64:187-194

Groffman P, Butterbach-Bahl K, Fulweiler R, Gold A, Morse J, Stander E, Tague C, Tonitto C, Vidon P (2009) Challenges to incorporating spatially and temporally explicit phenomena (hotspots and hot moments) in denitrification models. Biogeochemistry 92:49-77

Groffman PM (1991) Ecology of nitrification and denitrification in soil evaluated at scales relevant to atmospheric chemistry. In: Whitman WB, Rogers J (eds) Microbial production and consumption of greenhouse gases: methane. Nitrogen Oxides and Halomethanes American Society of Microbiology, Washington DC, pp 201-217

Groffman PM, Tiedje JM (1988) Denitrification hysteresis during wetting and drying cycles in soil. Soil Sci Soc Am J 52:1626-1629

Groffman PM, Tiedje JM (1989) Denitrification in north temperate forest soilsspatial and temporal patterns at the landscape and seasonal scales. Soil Biol Biochem 21:613-620

Groffman PM, Altabet MA, Bohlke JK, Butterbach-Bahl K, David MB, Firestone MK, Giblin AE, Kana TM, Nielsen LP, Voytek MA (2006) Methods for measuring denitrification: diverse approaches to a difficult problem. Ecol Appl 16:2091-2122

Haas E, Klatt S, Fröhlich A, Kraft P, Werner C, Kiese R, Grote R, Breuer L, Butterbach-Bahl K (2012) LandscapeDNDC: a process model for simulation of biosphere-atmosphere-hydrosphere exchange processes at site and regional scale. Landsc Ecol 27, in press

Haider K, Mosier A, Heinemeyer O (1987) The effect of growing plants on denitrification at high soil nitrate concentrations. Soil Sci Soc Am J 51:97-102

Harms TK, Grimm NB (2008) Hot spots and hot moments of carbon and nitrogen dynamics in a semiarid riparian zone. J Geophys Res-Biogeo 113:G101020

Hofstra N, Bouwman A (2005) Denitrification in agricultural soils: summarizing published data and estimating global annual rates. Nutr Cycl Agroecosyst $72: 267-278$
Houlton BZ, Bai E (2009) Imprint of denitrifying bacteria on the global terrestrial biosphere. Proc Natl Acad Sci U S A 106:21713-21716

Houlton BZ, Sigman DM, Hedin LO (2006) Isotopic evidence for large gaseous nitrogen losses from tropical rainforests. Proc Natl Acad Sci U S A 103:8745-8750

Howarth RW, Billen G, Swaney D, Townsend A, Jaworski N, Lajtha K, Downing JA, Elmgren R, Caraco N, Jordan T, Berendse F, Freney J, Kudeyarov V, Murdoch P, Zhu ZL (1996) Regional nitrogen budgets and riverine N\&P fluxes for the drainages to the North Atlantic Ocean: natural and human influences. Biogeochemistry 35:75-139

Huygens D, Boeckx P, Vermeulen J, De Paepe X, Park A, Barker S, Pullan C, Van Cleemput $O$ (2005) Advances in coupling a commercial total organic carbon analyser with an isotope ratio mass spectrometer to determine the isotopic signal of the total dissolved nitrogen pool. Rapid Commun Mass Spectrom 19:3232-3238

Kandeler E, Deiglmayr K, Tscherko D, Bru D, Philippot L (2006) Abundance of narG, nirS, nirk, and nosZ genes of denitrifying bacteria during primary successions of a glacier foreland. Appl Environ Microbiol 72:5957-5962

Kendall C (1998) Tracing nitrogen sources and cycling. In: Kendall C, McDonnell JJ (eds) Isotope tracers in catchment hydrology. Elsevier Scientific, New York, pp 519-576

Kendall C, Elliott EM, Wankel SD (2007) Tracing anthropogenic inputs of nitrogen to ecosystems. In: Michener RM, Lajtha K (eds) Stable isotopes in ecology and environmental science, 2nd edn. Blackwell Scientific, London, pp 375-449

Kool DM, Wrage N, Oenema O, Van Kessel C, Van Groenigen JW (2011) Oxygen exchange with water alters the oxygen isotopic signature of nitrate in soil ecosystems. Soil Biol Biochem 43:1180-1185

Kulkarni MV, Groffman PM, Yavitt JB (2008) Solving the global nitrogen problem: it's a gas! Front Ecol Environ 6:199-206

Li CS, Aber J, Stange F, Butterbach-Bahl K, Papen H (2000) A process-oriented model of $\mathrm{N}_{2} \mathrm{O}$ and $\mathrm{NO}$ emissions from forest soils: 1. Model development. J Geophys Res-Atmos 105:4369-4384

Liptzin D, Silver W, Detto M (2011) Temporal dynamics in soil oxygen and greenhouse gases in two humid tropical forests. Ecosystems 14:171-182

Lowrance R (1992) Nitrogen outputs from a field size agricultural watershed. J Environ Qual 21:602-607

Martin ME, Plourde LC, Ollinge SV, Smith ML, McNeil BE (2008) A generalizable method for remote sensing of canopy nitrogen across a wide range of forest ecosystems. Remote Sens Environ 112:3511-3519

McClain ME, Boyer EW, Dent CL, Gergel SE, Grimm NB, Groffman PM, Hart SC, Harvey JW, Johnston CA, Mayorga E, McDowell WH, Pinay G (2003) Biogeochemical hot spots and hot moments at the interface of terrestrial and aquatic ecosystems. Ecosystems 6:301-312

Nicholls JC, Trimmer M (2009) Widespread occurrence of the anammox reaction in estuarine sediments. Aquat Microb Ecol 55:105-113

NRC (1992) Rethinking the ozone problem in urban and regional Air pollution. National Academy Press, Washington DC

Ollinger SV, Richardson AD, Martin ME, Hollinger DY, Frolking SE, Reich PB, Plourde LC, Katuld GG, Mungere JW, Orend R, Smith M-L, Paw UKT, Bolstad PV, Cook BD, Daya MC, Martin TA, Monson RK, Schmid HP (2008) Canopy nitrogen, carbon assimilation, and albedo in temperate and boreal forests: functional relations and potential climate feedbacks. Proc Natl Acad Sci U S A 105:19336-19341

Ollinger SV, Smith ML, Martin ME, Hallett RA, Goodale CL, Aber JD (2002) Regional variation in foliar chemistry and $\mathrm{N}$ cycling among forests of diverse history and composition. Ecology 83:339-355

Parkin TB (1987) Soil microsites as a source of denitrification variability. Soil Sci Soc Am J 51:1194-1199

Parkin TB, Starr JL, Meisinger JJ (1987) Influence of sample size on measurement of soil denitrification. Soil Sci Soc Am J 51:1492-1501

Philippot L, Hallin S, Schloter M (2007) Ecology of denitrifying prokaryotes in agricultural soil. Adv Agron 96:249-305

Philippot L, Čuhel J, Saby NPA, Chèneby D, Chroňáková A, Bru D, Arrouays D, Martin-Laurent F, Šimek M (2009) Mapping field-scale spatial patterns of size and activity of the denitrifier community. Environ Microbiol 11:1518-1526

Prather M, Derwent R, Ehhalt D, Fraser PJ, Sanhueza E, Zhou X (1995) Other trace gases and atmospheric chemistry. In: Houghton JT, Meiro Filho LG, Callander BA, Harris N, Kattenburg A, Maskell K (eds) Climate change 1994. Radiative forcing of climate change and an evaluation of the IPCC IS92 Emission Scenarios. Cambridge University Press, New York, pp 73-126

Reddy KR, Patrick WH (1984) Nitrogen transformations and loss in flooded soils and sediments. CRC Crit Rev Environ Control 13:273-309 
Robertson GP, Huston MA, Evans FC, Tiedje JM (1988) Spatial variability in a successional plant community: patterns of nitrogen availability. Ecology 69:1517-1524

Rolston DE, Broadbent FE, Goldhamer DA (1979) Field measurement of denitrification: II. Mass balance and sampling uncertainty. Soil Sci Soc Am J 43:703-708

Seitzinger S, Harrison JA, Bohlke JK, Bouwman AF, Lowrance R, Peterson B, Tobias C, Van Drecht G (2006) Denitrification across landscapes and waterscapes: a synthesis. Ecol Appl 16:2064-2090

Sexstone AJ, Revsbech NP, Parkin TB, Tiedje JM (1985) Direct measurement of oxygen profiles and denitrification rates in soil aggregates. Soil Sci Soc Am J 49:645-651

Sigman DM, Casciotti KL, Andreani M, Barford C, Galanter M, Bohlke JK (2001) A bacterial method for the nitrogen isotopic analysis of nitrate in seawater and freshwater. Anal Chem 73:4145-4153

Silver WL, Lugo AE, Keller M (1999) Soil oxygen availability and biogeochemistry along rainfall and topographic gradients in upland wet tropical forest soils. Biogeochemistry 44:301-328

Smith KA (1980) A model of the extent of anaerobic zones in aggregated soils, and its potential application to estimates of denitrification. J Soil Sci 31:263-277

Söderlund R, Svensson BH (1977) The global nitrogen cycle. In: Svensson BH, Söderlund R (eds) Nitrogen, phosphorus and sulfur-global cycles. SCOPE report 7. Ecological Bulletins, Stockholm, pp 23-73

Stange CF, Spott O, Müller C (2009) An inverse abundance approach to separate soil nitrogen pools and gaseous nitrogen fluxes into fractions related to ammonium, nitrate and soil organic nitrogen. Eur J Soil Sci 60:907-915

Steinheimer TR, Scoggin KD, Kramer LA (1998) Agricultural chemical movement through a field-size watershed in lowa: subsurface hydrology and distribution of nitrate in groundwater. Environ Sci Technol 32:1039-1047

Swerts M, Uytterhoeven G, Merckx R, Vlassak K (1995) Semicontinuous measurement of soil atmosphere gases with gas-flow soil core method. Soil Sci Soc Am J 59:1336-1342

Tague C (2009) Modeling hydrologic controls on denitrification: sensitivity to parameter uncertainty and landscape representation. Biogeochemistry 92:79-90

Tague CL, Band LE (2004) RHESSys: regional hydro-ecologic simulation systeman object oriented approach to spatially distributed modeling of carbon, water and nutrient cycling. Earth Interact 8, Paper 19

Tague C, Band L, Kenworthy S, Tenebaum D (2010) Plot- and watershed-scale soil moisture variability in a humid Piedmont watershed. Water Resour Res 46: W12541

Van Breemen N, Boyer EW, Goodale CL, Jaworski NA, Paustian K, Seitzinger SP, Lajtha K, Mayer B, Van Dam D, Howarth RW, Nadelhoffer KJ, Eve M, Billen G (2002) Where did all the nitrogen go? Fate of nitrogen inputs to large watersheds in the northeastern USA. Biogeochemistry 57:267-293

Vidon P, Allan C, Burns D, Duval TP, Gurwick N, Inamdar S, Lowrance R, Okay J, Scott D, Sebestyen S (2010) Hot spots and hot moments in riparian zones: potential for improved water quality management. JAWRA J Am Water Resour As 46:278-298

Vitousek PM, Howarth RW (1991) Nitrogen limitation on land and in the seahow can it occur? Biogeochemistry 13:87-115

Wallenstein MD, Myrold DD, Firestone M, Voytek M (2006) Environmental controls on denitrifying communities and denitrification rates: insights from molecular methods. Ecol Appl 16:2143-2152

Walter MT, Walter MF, Brooks ES, Steenhuis TS, Boll J, Weiler K (2000) Hydrologically sensitive areas: variable source area hydrology implications for water quality risk assessment. J Soil Water Conserv 55:277-284

Wang R, Willibald G, Feng Q, Zheng X, Liao T, B̈̈ggemann N, Butterbach-Bahl K (2011a) Measurement of $\mathrm{N}_{2}, \mathrm{~N}_{2} \mathrm{O}, \mathrm{NO}$, and $\mathrm{CO}_{2}$ emissions from soil with the gas-flow-soil-core technique. Environ Sci Technol 45:6066-6072

Wang S-Y, Sudduth EB, Wallenstein MD, Wright JP, Bernhardt ES (2011b) Watershed urbanization alters the composition and function of stream bacterial communities. PLoS One 6:e22972

Well $\mathrm{R}$, Flessa $\mathrm{H}$ (2009) Isotopologue signatures of $\mathrm{N}_{2} \mathrm{O}$ produced by denitrification in soils. J Geophys Res-Biogeo 114:G02020

Woldendorp JW (1962) The quantitative influence of the rhizosphere on denitrification. Plant Soil 17:267-270

Yang WH, Silver WL (2012) Application of the N2/Ar technique to measuring soilatmosphere N2 fluxes. Rapid Commun Mass Spectrom 26:449-459

Yang WH, Weber KA, Silver WL (2012) Nitrogen loss from soil through anaerobic ammonium oxidation coupled to iron reduction. Nature Geosci 5:538-541

doi:10.1186/2192-1709-1-11

Cite this article as: Groffman: Terrestrial denitrification: challenges and opportunities. Ecological Processes 2012 1:11.

\section{Submit your manuscript to a SpringerOpen ${ }^{\odot}$ journal and benefit from:}

- Convenient online submission

- Rigorous peer review

- Immediate publication on acceptance

- Open access: articles freely available online

High visibility within the field

- Retaining the copyright to your article

Submit your next manuscript at $>$ springeropen.com 